\title{
Tingkat Kepuasan Konsumen terhadap Pelayanan Kefarmasian di Apotek Ganesha Farma Kabupaten Lamongan
}

\author{
Zahrotun Nisa'*1, Hajar Sugihantoro ${ }^{1}$, Ach. Syahrir ${ }^{1}$, Dhani Wijaya ${ }^{1}$ \\ ${ }^{1}$ Program Studi Farmasi, Fakultas Kedokteran dan Ilmu Kesehatan, UIN Maulana Malik Ibrahim Malang, Malang-Indonesia \\ *E-mail: zahrotunnisa1998@gmail.com
}

\begin{abstract}
Pharmaceutical service is a form of health service in pharmacy as an inseparable unit that plays a significant role in improving the quality of life of patients and also increasing patient satisfaction. Based on the preliminary study, the services whose provided by the Ganesha Farma Pharmacy staff are less satisfying to consumers, related to the friendliness of the pharmacy staff and the lack of provision of drug information by pharmacy staff. Therefore, in this study, it is expected to know the level of customer satisfaction at the Ganesha Farma Pharmacy, Lamongan Regency. The purpose of this study was to determine the level of customer satisfaction with pharmaceutical service at Ganesha Farma Pharmacy in Lamongan Regency. The type of research was descriptive with a quantitative approach. The sampling method was non-probability sampling with the purposive sampling technique. The samples obtained were 100 respondents. The method of calculating the level of customer satisfaction was the Customer Satisfaction Index (CSI) method. The results showed that the level of satisfaction at the reliability dimension of $70.8 \%$ (satisfied), responsivenesss 68.8\% (satisfied), assurance 69\% (satisfied), empathy 69.8 (satisfied), tangible $69.4 \%$ (satisfied). The conclusion of this study is the level of customer satisfaction towards pharmaceutical services at Ganesha Farma Pharmacy, Lamongan Regency is $69.56 \%$ with the satisfied category.
\end{abstract}

Keywords: Level of customer satisfaction, Pharmacy, Pharmaceutical services

\begin{abstract}
ABSTRAK
Apotek merupakan sarana pelayanan kesehatan. Pelayanan kefarmasian merupakan salah satu bentuk dari pelayanan kesehatan yang berada di Apotek dan merupakan satu kesatuan yang tidak terpisahkan yang berperan penting dalam meningkatkan kualitas hidup pasien dan juga meningkatkan kepuasan pasien. Berdasarkan studi pendahuluan, pada pelayanan yang diberikan oleh petugas Apotek Ganesha Farma kurang memuaskan konsumen, terkait keramahan petugas apotek dan kurangnya pemberian informasi obat oleh petugas apotek. Maka dari itu dalam penelitian ini diharapkan dapat mengetahui tigkat kepuasan konsumen di Apotek Ganesha Farma Kabupaten Lamongan. Tujuan penelitian ini untuk mengetahui tingkat kepuasan konsumen terhadap pelayanan kefarmasian di apotek Ganesha Farma Kabupaten Lamongan. Jenis penelitian deskriptif dengan pendekatan kuatitatif. Cara pengambilan sampel dengan metode non-probability sampling dengan Teknik purposive sampling. Sampel yang diperoleh sebanyak 100 responden. Metode perhitungan tingkat kepuasan konsumen menggunakan metode Customer Satisfiaction Index (CSI). Hasil penelitian didapatkan tingkat kepuasan pada diensi kehandalan $70,8 \%$ (puas), ketanggapan 68,8\% (puas), jaminan 69\% (puas), kepedulian 69,8 (puas), bukti fisik 69,4\% (puas). Kesimpulan penelitiaan ini tingkat kepuasan konsumen terhadap pelayanan kefarmasian di Apotek Ganesha Farma Kabupaten Lamongan sebesar 69,56\% dengan kategori puas.
\end{abstract}

Kata Kunci: Tingkat kepuasan konsumen, Apotek, Pelayanan kefarmasian 


\section{Pendahuluan}

Kesehatan merupakan hak asasi manusia, setiap orang memiliki hak untuk hidup layak, baik dalam kesehatan pribadi maupun keluarganya. Menurut Undang-Undang Dasar Negara Republik Indonesia Tahun 1945 pasal $28 \mathrm{H}$ ayat 1 menyatakan bahwa setiap orang berhak hidup sejahtera lahir dan batin, bertempat tinggal, dan mendapatkan lingkungan hidup yang baik dan sehat serta berhak mendapatkan layanan kesehatan. Salah satu fasilitas pelayanan kesehatan adalah Apotek.

Apotek adalah sarana pelayanan kefarmasian tempat dilakukan praktik kefarmasian oleh Apoteker [1]. Pelayanan Kefarmasian adalah suatu pelayanan langsung dan bertanggung jawab kepada pasien yang berkaitan dengan sediaan farmasi dengan maksud mencapai hasil yang pasti untuk meningkatkan mutu kehidupan pasien [1]. Pelayanan kefarmasian di masa sekarang telah berubah orientasinya, dari drug oriented menjadi patient oriented. Peran apoteker dalam pelaksanaan pelayanan kefarmasian ke orientasi patient oriented harus dimulai dengan meningkatkan pengetahuan, keterampilan, dan perilaku untuk dapat melaksanakan interaksi langsung dengan pasien [2].

Pelayanan kefarmasian dikatakan bermutu bila pelayanan tersebut dilakukan sesuai dengan standar yang ada [3]. Menurut Depkes RI (2016), Standar pelayanan kefarmasian di apotek merupakan bagian yang tidak terpisahkan dari sistem pelayanan kesehatan apotek yang berorientasi kepada pelayanan pasien, penyediaan sediaan farmasi, alat kesehatan, dan bahan medis habis pakai yang bermutu dan terjangkau bagi semua lapisan masyarakat. Salah satu tujuan adanya standar kefarmasian tersebut adalah untuk meningkatkan mutu pelayanan kefarmasian di apotek dan memberikan pelayanan yang memuaskan kepada konsumen [1].

Kepuasan konsumen adalah suatu tingkat perasaan yang timbul sebagai akibat dari kinerja layanan kesehatan yang diperolehnya setelah konsumen membandingkannya dengan apa yang diharapkan [4]. Kepuasan menjadi bagian penting dalam pelayanan kefarmasian sebab kepuasan pasien menjadi tujuan pelayanan kefarmasian yang berguna untuk meningkatkan hasil pelayanan kesehatan secara medis, seperti kepatuhan terhadap pengobatan [5]. Penelitian yang dilakukan Monika, Chreisye dan Paul (2015), membuktikan bahwa terdapat hubungan antara pelayanan kefarmasian dengan kepuasan konsumen [6]. Penelitian yang dilakukan Putri (2017), menunjukkan tingkat kepuasan pasien terhadap pelayanan kefarmasian memiliki pengaruh positif terhadap loyalitas pasien, sehingga semakin tinggi tingkat kepuasan semakin loyal pasien [7].

Menurut Parasuraman (1988), ada lima dimensi mutu pelayanan untuk melihat kepuasan konsumen yang dikenal dengan metode SERVQUAL, yang pertama yakni dimensi realibility, yaitu dimensi mutu pelayanan untuk melihat keakuratan dan konsisten pelayanan [8]. Penelitian yang dilakukan oleh Dewi (2014) [9] , di Apotek Non Praktek Dokter di Kuta Utara menunjukkan tingkat kepuasan pada dimensi ini rendah, dikarenakan kemampuan apoteker untuk menjelaskan proses terjadinya penyakit dan gejala penyakit pasien masih kurang memenuhi harapan pasien. Yang kedua dimensi responsivenesss, yakni dimensi mutu pelayanan untuk melihat kecepatan dan ketepatan pelayanan. Penelitian yang dilakukan oleh Fithria dan Umi (2014) [10], di IFRSUD Tugurejo menunjukkan tingkat kepuasan pada dimensi ini rendah, dikarenakan jumlah pasien yang tidak seimbang dengan jumlah petugas farmasi yang ada. Ketiga, dimensi assurance, yakni dimensi mutu pelayanan untuk melihat rasa percaya dan keyakinan dalam pelayanan. Penelitian yang dilakukan oleh Yuniar (2016) [11], pelayanan kefarmasian di Apotek Kota Kabupaten Tanggerang Selatan, Serang, Bekasi, Bogor, Yogyakarta, Bantul, Solo dan Sragen pada dimensi ini memiliki tingkat kepuasan paling rendah diantara dimensi lain. Keempat, dimensi empathy, yakni dimensi mutu pelayanan untuk melihat keramahan, perhatian. Penelitian yang dilakukan oleh Harijono dan Bobby (2011) [12], di bagian farmasi RSK St Vincentius A Paulo Surabaya, menunjukkan tingkat kepuasan pada dimensi ini rendah, hal ini dikarenakan keramahan dan kesopanan petugas farmasi dalam menjalankan tugasnya dinilai masih jauh dari harapan pasien. Kelima, dimensi tangible, yakni dimensi mutu pelayanan untuk melihat penampilan fisik dari fasilitas, peralatan, karyawan. Penelitian yang dilakukan oleh Pareraway dkk (2016), di Apotek Rumah Sakit Umum Persahabatan Prof. Dr. R. D. Kandou Manado menunjukkan tingkat kepuasan pada dimensi ini rendah, dikarenakan minimnya informasi obat secara aktif berupa leaflet, brosur/ komputerisasi dan lokasi apotek yang susah dijangkau [13].

Berdasarkan data hasil penelitian-penelitian yang telah dilakukan oleh peneliti lain, penelitian kali ini dilakukan di Apotek Ganesha Farma karena pada apotek tersebut belum pernah dilakukan penelitian terkait kepuasan konsumen apotek terhadap pelayanan kefarmasian. Berdasarkan hasil observasi yang dilakukan peneliti oleh 10 konsumen apotek yang diwawancarai mengatakan bahwa sebagian konsumen merasa kurang puas terhadap pelayanan kefarmasian yang diberikan oleh petugas apotek terkait keramahan petugas apotek dan kurangnya pemberian informasi obat oleh petugas apotek. Maka dari itu dalam penelitian ini diharapkan dapat mengetahui tigkat kepuasan konsumen di Apotek Ganesha Farma Kabupaten Lamongan.

\section{Metode Penelitian}

\subsection{Jenis Penelitian}

Penelitian ini merupakan jenis penelitian deksriptif dengan pendekatan kuantitatif dan rancangan penelitian Cross Sectional. 


\subsection{Tempat dan Waktu Penelitian}

Penelitian dilakukan di Apotek Ganesha Farma pada bulan Mei 2020 .

\subsection{Populasi Penelitian}

Populasi penelitian adalah konsumen yang datang ke Apotek Ganesha Farma.

\subsection{Sampel Penelitian}

Sampel penelitian ini adalah konsumen yang membeli obat di Apotek Ganehsa Farma, berdasarkan kriteria inklusi. Teknik pengambilan sampel penelitian ini menggunakan NonProbability Sampling, dan metode pengambilan sampelnya menggunakan Purposive Sampling.

Kriteria inklusi dan eksklusi pada penelitian ini adalah sebagai berikut:

a. Kriteria Inklusi

1) Konsumen berumur 17-55 tahun.

2) Konsumen bisa berkomunikasi, membaca, dan menulis dengan baik.

3) Konsumen yang bersedia menjadi responden penelitian.

b. Kriteria Eksklusi

1) Konsumen yang tidak mendapatkan obat yang ingin dibeli/ dibutuhkan.

\subsection{Analisis Data}

Analisis data yang digunakan pada penelitian ini adalah CSI (Customer Satisfiaction Indeks). Analisis data ini terdiri dari 4 tahap yaitu:

1. Menentukan Mean Importance Score (MIS) dan Mean Satisfaction Score (MSS) Nilai ini berasal dari rata-rata kepentingan (importance) tiap atribut dan rata-rata kepuasan (satisfaction) tiap atribut.

$$
M I S=\frac{\sum_{i=1}^{n} Y_{i}}{n} \quad M S S=\frac{\sum_{i=1}^{n} X_{i}}{n}
$$

Keterangan:

$\mathrm{n}$ = Jumlah Pelanggan (Responden)

Yi = Nilai Kepentingan Atribut Y ke i

$\mathrm{Xi}=$ Nilai Kepuasan Atribut $\mathrm{X}$ ke i

2. Menghitung Weight Factors (WF), merupakan persentase nilai Mean Importance Score (MIS) per atribut terhadap Mean Importance Score (MIS) seluruh atribut.

$$
W F=\frac{M I S i}{\sum_{i=1}^{p} M I S i} \times 100 \%
$$

Keterangan:

$$
\begin{aligned}
& \text { MISi }=\text { Mean Importance Score } \\
& \mathrm{P} \quad=\text { Jumlah Atribut } \\
& 1 \quad=\text { Atribut ke-i }
\end{aligned}
$$

3. Menghitung Weight Score (WS), merupakan perkalian antara Weight Factors (WF) dengan rata-rata tingkat tingkat kepuasan (Mean Satisfaction Score/MSS).

$$
\mathrm{WSi}=\mathrm{WFi} \quad \mathrm{X} \mathrm{MSSi}
$$

4. Menghitung Customer Satisfaction Index (CSI)

$$
\mathrm{CSI}=\frac{\sum_{k=1}^{p} \text { WSi }}{\text { HS (4) }} \times 100 \% \quad \text { HS = Highest Scale }
$$

Dari hasil perhitungan yang didapat, tingkat kepuasan dapat dikategorikan ke dalam kategori berikut:

\begin{tabular}{cc}
\hline Kategori & Persentase \\
\hline Sangat Tidak Puas & $25 \%-43,75 \%$ \\
Tidak Puas & $43,76 \%-62,50 \%$ \\
Puas & $62,51 \%-81,25 \%$ \\
Sangat Puas & $81,26 \%-100 \%$ \\
\hline
\end{tabular}

\section{Hasil dan Pembahasan}

\subsection{Hasil Uji Validitas Kuisioner}

Uji validitas adalah uji yang digunakan untuk menunjukkan sejauh mana alat ukur yang digunakan dalam mengukur sesuatu yang akan diukur. Suatu kuesioner dikatakan valid jika pertanyaan pada kuesioner mampu untuk mengungkapkan suatu yang akan diukur oleh kuesioner tersebut. Masing-masing item dikatakan valid apabila $r$ hitung > r table [14].

Pengujian validitas kuesioner dilakukan kepada 30 responden, sebagai syarat minimal untuk uji coba validitas. kuesioner diuji kepada 30 sampel dengan nilai signifikansi $5 \%$, sehingga didapatkan $r$ tabel sebesar 0,361 . Oleh karena itu apabila $\mathrm{r}$ hitung suatu pernyaatan $>0,361$ maka suatu pernyataan tersebut dikatakan valid, sedangkan apabila $\mathrm{r}$ hitung suatu pernyataan $<0,361$ maka suatu pernyataan tersebut dikatakan tidak valid.

Berdasarkan hasil pengujian validitas kuesioner tingkat harapan, diperoleh hasil bahwa dari 18 item pertanyaan semua dinyatakan valid. Hal ini dikarenakan nilai $r$ hitung yang diperoleh diatas lebih besar dari pada nilai $r$ tabel $(0,361)$ (tabel 1). Kemudian hasil pengujian validitas kuesioner tingkat kenyataan, diperoleh hasil bahwa dari 18 item pertanyaan semua menunjukkan nilai $\mathrm{r}$ hitung diatas lebih 
besar dari pada nilai $\mathrm{r}$ tabel $(0,361)$ yang berarti menunjukkan hasil valid (tabel 2).

\subsection{Hasil Uji Reliabilitas Kuisioner}

Reliabilitas adalah alat untuk mengukur suatu kuesioner yang merupakan indikator dari variabel tersebut. Suatu kuesioner dikatakan reliabel atau handal jika jawaban seseorang terhadap pertanyaan tersebut konsisten atau stabil dari waktu ke waktu [14].

Metode uji reliabilitas yang digunakan dalam penelitian ini adalah uji reliabilitas Cronbach's Alpha dengan bantuan program SPSS 16, Jika nilai koefisien Alpha lebih besar dari 0,60 maka disimpulkan kuesioner penelitian tersebut handal atau reliabel, apabila semua variabel reliabel maka data yang dianalisis bisa dipercaya dan konsisten sehingga dapat digunakan untuk pengujian berikutnya.

Berdasarkan hasil pengujian reliabilitas kuesioner tingkat harapan, dapat diketahui bahwa nilai cronbach's alpha pada kuesioner semua variable untuk tingkat harapan sebesar 0, 948. Dimana nilai tersebut lebih dari 0,60 sehingga kuesioner yang digunakan pada penelitian ini sudah handal atau reliabel (tabel 3). Adapun pada hasil pengujian reliabilitas kuesioner tingkat kenyataan, dapat diketahui bahwa nilai cronbach's alpha pada kuesioner semua variable untuk tingkat harapan sebesar 0, 958. Dimana nilai tersebut lebih dari 0,60 sehingga kuesioner yang digunakan pada penelitian ini sudah handal atau reliabel (tabel 4).

\subsection{Karakteristik Responden Berdasarkan Jenis Kelamin}

Berdasarkan data karakteristik responden berdasarkan jenis kelamin, diketahui bahwa dari 100 responden yang berjenis kelamin laki-laki sebanyak $52 \%$ dan yang berjenis kelamin perempuan sebanyak $48 \%$. Dari data tersebut dapat diketahui bahwasanya jenis kelamin responden yang paling banyak adalah responden berjenis kelamin laki-laki. Hal ini sesuai dengan data demografi penduduk di Kabupaten Lamongan, dimana jumlah penduduk berjenis kelamin lakilaki (681.587) lebih banyak dibanding penduduk yang berjenis kelamin perempuan (679.400) [15].

\subsection{Karakteristik Responden Berdasarkan Umur}

Berdasarkan data karakteristik responden berdasarkan umur, didapatkan hasil bahwa dari 100 responden yang berumur 17-25 tahun sebanyak 26\%, umur 26-35 tahun sebnyak 23\%, umur 36-45 sebanyak $41 \%$ dan responden dengan umur 46-55 tahun sebanyak 10\%. Dari data tersebut dapat diketahui bahwa kebanyakan responden yang membeli obat di Apotek Ganesha Farma adalah responden dengan umur 36-45 tahun dan umur 17-25 tahun. Data tersebut sesuai dengan komposisi penduduk di Kabupaten Lamongan, dimana kelompok umur produktif (umur 15-64 tahun) masih mendominasi presentase. Dengan jumlah kelompok komposisi penduduk Kabupaten Lamongan menurut kelompok umur, yang berusia produktif laki-laki (15-64 tahun) sebesar 407.445 (33.75\%) sedangkan berusia produktif perempuan (15 - 64 tahun) sebesar 433.299 (35.89\%) [16].

Menurut penelitian yang dilakukan oleh Pangala (2014) menyatakan bahwa pasien dengan rentang umur 18-40 tahun memiliki presentase terbesar yaitu $87 \%$ sedangkan pasien dengan umur 60 tahun keatas memiliki presentase terkecil yaitu 9,09\% [17]. Menurut penelitian Misnaniarti (2017) [18] orang yang lanjut usia akan mengalami masalah penurunan daya tahan tubuh sehingga rentan terkena penyakit. Namun pada penelitian ini usia 46-55 tahun tidak menjadi yang tertiggi, karena penelitian ini dilakukan pada masa Covid-19, dimana penduduk dengan usia lanjut dibatasi untuk beraktivitas diluar rumah, karena rentan terpapar Covid-19.

\subsection{Karakteristik Responden Berdasarkan Pekerjaan}

Berdasarkan data karakteristik responden berdasarkan pekerjaan, didapatkan bahwa hasil paling banyak terdapat pada pekerjaan petani yakni sebanyak 23 orang dengan persentase sebesar 23\%. Hal ini sesuai dengan demografi penduduk Kabupaten Lamongan, dimana 312.256 jiwa dari total penduduk Kabupaten Lamongan bermata pencaharian dari bidang pertanian, sedangkan sisanya merupakan wiraswasta, nelayan, guru, ibu rumah tangga, dll [15].

Mahasiswa/mahasiswi menduduki presentase tertinggi kedua pada data pekerjaan responden pada penelitian ini, dikarenakan pada saat pengambilan data bersamaan dengan adanya wabah virus corona yang telah memasuki negara Indonesia, hal ini menyebabkan kegiatan belajar mengajar dikampus diliburkan, sehingga mahasiswa/mahasiswi memilih untuk kembali ke kampung halaman. Dibuktikan dengan hasil mewawancarai responden yang berprofesi sebagai mahasiswa, dimana mahasiswi/mahasiswa yang datang ke Apotek Ganesha Farma merupakan mahasiswa perantauan dari kota besar, seperti: Jogja, Malang, Surabaya dan Gresik.

\subsection{Distribusi Jawaban Pada Dimensi Tingkat Kepuasan Dan Harapan Konsumen Terhadap Pelayanan Kefarmasian Di Apotek Ganesha Farma}

\subsubsection{Dimensi kehandalan (reliability)}

Dimensi reliability (kehandalan) merupakan dimensi kualitas pelayanan yang berupa kemampuan untuk memberikan pelayanan sesuai janji yang ditawarkan, sehingga dapat memberikan pelayanan yang optimal dan akurat [19]. 
Berdasarkan tabel 8, menunjukkan bahwa pada pernyataan petugas apotek memberikan informasi terkait nama, kandungan, jumlah, dan dosis obat terdapat 97\% responden menyatakan penting dan sangat penting, hal ini didukung dengan penelitian oleh Priyanto, dkk (2010) [20], informasi tentang dosis pemakaian obat selalu diberikan karena merupakan hal yang sangat penting dalam mengkonsumsi obat. Kesalahan dalam dosis obat dapat membahayakan kondisi pasien itu sendiri. Sehingga informasi tentang dosis pemakaian obat harus benar-benar diberikan kepada pasien dengan baik sehingga pasien tidak mengalami masalah dalam mengkonsumsi obat yang pada akhirnya akan berakibat baik pada tercapainya tujuan terapi. Pernyataan petugas apotek memberi informasi terkait cara penggunaan obat terdapat $99 \%$ responden menyatakan penting dan sangat penting. Menurut Aprilia (2008) [21], informasi cara penggunaan obat harus diberitahukan dengan jelas kepada konsumen saat menyerahkan obat karena ketidakjelasan dalam pemakaian suatu obat akan mempengaruhi ketepatan konsumen dalam menggunakan obat, sehingga akan berpengaruh terhadap keberhasilan pengobatan dan kualitas hidup konsumen.Pernyataan petugas apotek memberi informasi terkait aturan pakai obat terdapat $98 \%$ responden menyatakan penting dan sangat penting, pernyataan petugas apotek memberi informasi tentang efek samping obat terdapat 97\% responden menyatakan penting dan sangat penting. Menurut Aslam, dkk (2003) [22], informasi tentang efek samping obat yang digunakan perlu disampaikan kepada konsumen karena pemberitahuan tentang efek samping ini bertujuan agar konsumen tidak khawatir akan penggunaan obat selama terapi. Menurut Hartini dan Sulasmono (2007) [23], kepahaman konsumen dengan informasi yang diberikan oleh petugas apotek akan mempengaruhi tingkat keberhasilan dalam pengobatan. Hal ini penting karena kepahaman konsumen mengenai informasi segala sesuatu yang telah dijelaskan oleh petugas apotek akan sangat mempengaruhi kepatuhan dan keteraturan konsumen dalam meminum obat serta mengetahui efek samping dari obat yang digunakan.

Pernyataan petugas apotek menjelaskan informasi obat dengan bahasa yang mudah dimengeti, yang menilai penting $38 \%$ dan sangat penting $60 \%$, pernyataan ini penting ditanyakan karena berdasarkan Keputusan Menteri Kesehatan RI Nomor 1027/ Menkes/ SK/IX/2004 tentang Standar Pelayanan Kefarmasian di Apotek [24], apoteker harus memberikan informasi yang benar, jelas dan mudah dimengerti, akurat, tidak bias, etis, bijaksana, dan terkini kepada pasien di apotek. Pernyataan petugas apotek memberikan kesempatan kepada konsumen untuk menceritakan keluhannya, yang menilai penting $49 \%$ dan sangat penting $51 \%$. Pernyataan ini penting ditanyakan karena salah satu tugas apoteker berkomunikasi efektif secara aktif untuk menggali permasalahan pasien terkait keluhan yang disampaikan oleh pasien. Sehingga pada pelayanan kefarmasian apoteker dapat menjamin keamanan, ketepatan dan rasionalitas obat yang diterima pasien. Berdasarkan tabel data diatas, mayoritas konsumen menyatakan bahwa semua pernyataan pada dimensi reliability penting terhadap pelayanan kefarmasian di Apotek Ganesha Farma Kabupaten Lamongan.

Berdasarkan tabel 9, didapatkan hasil bahwa pada pernyataan, petugas apotek memberikan informasi terkait nama, kandungan, jumlah, dan dosis obat terdapat 56\% responden menyatakan puas dan sangat puas. Pernyataan petugas apotek memberi informasi terkait cara penggunaan obat terdapat $67 \%$ responden menyatakan puas dan sangat puas. Pernyataan petugas apotek memberi informasi terkait aturan pakai obat terdapat $38 \%$ responden menyatakan puas dan sangat puas. Pernyataan petugas apotek memberi informasi tentang efek samping obat terdapat $62 \%$ responden menyatakan puas dan sangat puas. Pernyataan petugas apotek menjelaskan informasi obat dengan bahasa yang mudah dimengeti terdapat $44 \%$ responden menyatakan puas dan sangat puas. Pernyataan petugas apotek memberikan kesempatan kepada konsumen untuk menceritakan keluhannya terdapat $62 \%$ responden menyatakan puas dan sangat puas. Berdasarkan data tersebut mayoritas responden menyatakan puas terhadap semua pernyataan pada dimensi reliability yang berarti petugas apotek di Apotek Ganesha Farma Kabupaten Lamongan telah melakukan pelayanan dengan baik akan tetapi pada penyataan keempat, petugas Apotek memberi informasi tentang efek samping obat mendapatkan presentase jawaban terendah dan masih terdapat $11 \%$ konsumen menyatakan tidak puas dan $27 \%$ konsumen menyatakan cukup puas. Menurut Ahaditomo (2004), permasalahan terkait efek samping obat tidak bisa dipandang sebelah mata karena dapat menimbulkan beberapa dampak negatif bagi konsumen baik dari segi psikologi, ekonomi dan juga keberhasilan terapi [25].

\subsubsection{Dimensi daya tanggap (responsivenesss)}

Dimensi responsivenesss (daya tanggap) merupakan dimensi kualitas pelayanan yang berupa kemauan pihak pemberi pelayanan kesehatan untuk memberikan informasi dan membantu merespon kebutuhan dan keinginan pasien dengan segera [18].

Berdasarkan tabel 10, didapatkan hasil bahwa pada pernyataan petugas apotek selalu siap melayani konsumen terdapat $96 \%$ responden menyatakan penting dan sangat penting, pernyataan ini penting ditanyakan karena menurut Mayang dan Supriyanto (2017) [26], jika petugas selalu sigap membatu konsumen yang ingin membeli obat maka konsumen merasa senang dengan pelayanan yang diberikan petugas dan konsumen tidak menunggu lama. Pernyataan petugas apotek mendengarkan keluhan konsumen dengan seksama terdapat 
98\% responden menyatakan penting dan sangat penting Pernyataan petugas apotek menanggapi pertanyaan konsumen terkait obat-obatan yang didapat terdapat $98 \%$ responden menyatakan penting dan sangat penting, pernyataan ini penting ditanyakan karena kepemahaman konsumen dengan informasi yang diberikan oleh petugas apotek akan mempengaruhi tingkat keberhasilan dalam pengobatan. Hal ini penting karena pemahaman konsumen mengenai segala sesuatu informasi yang telah dijelaskan oleh petugas apotek akan mempengaruhi kepatuhan dan keteraturan konsumen dalam menggunakan obat [2]. Berdasarkan data tersebut mayoritas konsumen menyatakan bawa semua pernyataan pada dimensi responsivenesss penting terhadap pelayanan kefarmasian di Apotek Ganesha Farma Kabupaten Lamongan.

Berdasarkan tabel 11, didapatkan hasil bahwa pada pernyataan petugas apotek selalu siap melayani konsumen terdapat $44 \%$ responden menyatakan puas dan sangat puas. Pada pernyataan petugas apotek mendengarkan keluhan konsumen dengan seksama terdapat $48 \%$ responden menyatakan puas dan sangat puas. Pada pernyataan petugas apotek menanggapi pertanyaan konsumen terkait obat-obatan yang didapat terdapat $49 \%$ responden menyatakan puas dan sangat puas. Berdasarkan data tersebut mayoritas konsumen merasakan puas terhadap semua pernyataan pada dimensi responsivenesss yang berarti petugas apotek di Apotek Ganesha Farma Kabupaten Lamongan telah melakukan pelayanan dengan baik, akan tetapi persentase konsumen yang merasa tidak puas masih tinggi terhadap pernyataan petugas apotek mendengarkan keluhan konsumen dengan seksama yaitu sebesar $12 \%$. Poin ini perlu diperhatikan karena menurut Mayang dan Supriyanto (2017) [26], jika petugas memberikan perhatian terhadap keluhan konsumen dengan baik maka konsumen akan merasa senang dengan perhatian yang diberikan. Dan sebaliknya jika konsumen tidak merasa didengarkan keluhannya serta tidak diperhatikan maka konsumen akan merasa kecewa, hal ini akan mempengaruhi kepuasan konsumen.

\subsubsection{Dimensi jaminan (assurance)}

Dimensi assurance (jaminan) merupakan dimensi mutu pelayanan yang berupa adanya jaminan yang mencakup pengetahuan dan ketrampilan petugas, kesopanan dan keramahan petugas, kemampuan petugas dalam berkomunikasi, sifat dapat dipercaya dan adanya jaminan keamanan [19].

Berdasarkan tabel 12, didapatkan hasil bahwa pada pernyataan obat yang diterima konsumen dalam kondisi baik dan benar terdapat $98 \%$ responden menyatakan penting dan sangat penting. Pernyataan ini penting ditanyakan karena obat yang diterima dalam kondisi baik dapat meyakinkan konsumen bahwa obat tersebut dalam keadaan layak konsumsi dan terjamin keaslianya. Kemudian pernyataan ini sesuai dengan Depkes RI (2016) [1], yang menyatakan bahwa tidak ada kejadian kesalahan pemberian obat. Dengan adanya peraturan tersebut petugas apotek menghindari adanya kesalahan pada saat pemberian obat dan meyakinkan konsumen dalam memperoleh obat dengan benar dimana akan berpengaruh pada keberhasilan pengobatan, sehingga konsumen yakin akan keahlian dan profesionalisme tenaga farmasi karena pemberian obat dengan benar merupakan tanggung jawab tenaga farmasi, sehingga dapat meningkatkan kepercayaan konsumen terhadap apotek.

Pernyataan mengenai petugas apotek mempunyai pengetahuan dan keterampilan yang baik dalam bekerja terdapat $96 \%$ responden menyatakan penting dan sangat penting, Berdasarkan data tersebut mayoritas konsumen menyatakan bahwa semua pernyataan pada dimensi assurance penting terhadap pelayanan kefarmasian di Apotek Ganesha Farma Kabupaten Lamongan

Dari tabel 13, didapatkan hasil bahwa pada pernyataan obat yang diterima konsumen dalam kondisi baik dan benar terdapat $49 \%$ responden menyatakan puas dan sangat puas. Pada pernyataan petugas apotek mempunyai pengetahuan dan keterampilan yang baik dalam bekerja terdapat $51 \%$ responden menyatakan puas dan sangat puas. Berdasarkan data tersebut mayoritas konsumen merasakan puas terhadap semua pernyataan pada dimensi assurance yang berarti petugas apotek di Apotek Ganesha Farma Kabupaten Lamongan telah melakukan pelayanan dengan baik, akan tetapi masih terdapat $13 \%$ konsumen menyatakan tidak puas terhadap pernyataan obat yang diterima konsumen dalam kondisi baik dan benar. pada pernyataan ini perlu adanya optimalisasi ketelitian petugas apotek dalam memberikan obat, karena menurut Kotler (2005), pengetahuan serta jaminan keamanan dan kepercayaan dalam pelayanan akan berdampak kepada tingkat kepuasan konsumen [27].

\subsubsection{Dimensi kepedulian (empathy)}

Dimensi Empathy (kepedulian) adalah dimensi kualitas pelayanan yang berupa pemberian perhatian yang sungguhsungguh dari pemberi pelayanan kepada konsumen secara individual [19].

Berdasarkan tabel 14, didapatkan hasil pada pernyataan petugas apotek memberikan perhatian yang tulus demi kesehatan pasien terdapat $68 \%$ responden menyatakan penting dan sangat penting, pernyataan ini penting ditanyakan karena menurut Karl (2005) [28] interaksi langsung yang dilakukan oleh petugas dalam melayani pelanggan harus dengan tulus dan penuh kepedulian karena dengan begitu dapat meningkatkan kepuasan pelanggan. Pernyataan kedua, petugas apotek mendengarkan pertanyaan dan keluhan pasien dengan sabar terdapat $100 \%$ responden menyatakan penting 
dan sangat penting, pernyataan ini penting ditanyakan karena menurut Wahyuni dan Sulistyowati (2015) menyatakan bahwa keramahan dan kesabaran petugas dalam menghadapi pasien memberikan kontribusi bagi kepuasan pasien [29].

Pernyataan ketiga mengenai petugas apotek ramah dan sopan melayani pasien terdapat $98 \%$ responden menyatakan penting dan sangat penting, pernyataan ini penting ditanyakan karena baik atau buruknya suatu pelayanan kesehatan menurut konsumen diantaranya adalah dari sikap petugas apotek. Pelayanan kesehatan dianggap baik karena petugasnya ramah, bersahabat, sabar dan komunikatif. Sebaliknya jika pelayanan kesehatan dianggap kurang baik karena petugasnya kasar dan berbicara kurang sopan [30]. Berdasarkan data tersebut mayoritas konsumen menyatakan bawa semua pernyataan pada dimensi empathy penting terhadap pelayanan kefarmasian di Apotek Ganesha Farma Kabupaten Lamongan.

Berdasarkan tabel 15, didapatkan hasil bahwa pada pernyataan petugas apotek memberikan perhatian yang tulus demi kesehatan konsumen terdapat $51 \%$ responden menyatakan puas dan sangat puas. Pada pernyataan petugas apotek mendengarkan pertanyaan dan keluhan konsumen dengan sabar terdapat $52 \%$ responden menyatakan puas dan sangat puas. Pada pernyataan petugas apotek ramah dan sopan melayani terdapat $52 \%$ responden menyatakan puas dan sangat puas. Berdasarkan data tersebut mayoritas konsumen merasakan puas terhadap semua pernyataan pada dimensi empathy yang berarti petetugas apotek di Apotek Ganesha Farma Kabupaten Lamongan telah melakukan pelayanan dengan baik, akan tetapi masih terdapat $11 \%$ konsumen menyatakan tidak puas terhadap pernyataan petugas apotek memberikan perhatian yang tulus demi kesehatan konsumen. Menurut Sholihah (2019), kepedulian petugas kefarmasian kepada pasien diperlukan agar pasien merasa dihormati dan diperhatikan [31].

\subsubsection{Dimensi bukti fisik (tangible)}

Dimensi tangibel (bukti fisik) merupakan tampilan pelayanan meliputi sarana prasarana yang perlu tersedia di suatu penyedia pelayanan kesehatan yang dapat dilihat secara langsung oleh pasien meliputi fasilitas fisik, perlengkapan, pegawai, dan sarana komunikasi [32].

Berdasarkan tabel 16, didapatkan hasil pada pernyataan kebersihan di lingkungan apotek terdapat 95\% responden menyatakan penting dan sangat penting, pernyataan ini penting ditanyakan karena kebersihan, kerapian dan kenyamanan diapotek akan berdampak pada tingkat kepuasan pasien [27]. Pernyataan kedua mengenai petugas apotek berpenampilan rapi dan bersih, responden terdapat $94 \%$ responden menyatakan penting dan sangat penting, Pernyataan ketiga mengenai ketersediaan obat yang lengkap, responden terdapat $90 \%$ responden menyatakan penting dan sangat penting, pernyataan ini penting ditanyakan karena ketersediaan obat merupakan salah satu pelayanan kefarmasian yang dilakukan dalam menentukan jenis dan jumlah obat yang ada didalam apotek. Ketersediaan obat dalam suatu apotek meliputi variasi jenis, tipe ukuran kemasan barang yang dijual, dan macam-maam rasa dari suatu produk yang akan dibeli. Dimana ketersediaan obat dalam apotek harus lengkap, sehingga dibutuhkan pengecekan persediaan obat secara rutin. Ketersediaan obat yang lengkap akan memudahkan masyarakat untuk mencari kebutuhan yang diperlukan.

Pernyataan keempat mengenai ketersediaan sumber informasi kesehatan (poster, brosur) terdapat $86 \%$ responden menyatakan penting dan sangat penting. Pernyataan ini penting ditanyakan karena tersedianya informasi kesehatan bagi pasien berupa brosur, leaflet, poster atau majalah kesehatan diharapkan dapat meningkatkan pengetahuan dan manfaat sehingga dapat memperbaiki kualitas hidup konsumen [2]. Berdasarkan data tersebut mayoritas konsumen menyatakan bawa semua pernyataan pada dimensi tangible penting terhadap pelayanan kefarmasian di Apotek Ganesha Farma Kabupaten Lamongan.

Berdasarkan tabel 17, menunjukkan bahwa pada pernyataan kebersihan di lingkungan apotek terdapat 55\% responden menyatakan puas dan sangat puas. Terkait pernyataan petugas apotek berpenampilan rapi dan bersih terdapat $46 \%$ responden menyatakan puas dan sangat puas. Pernyataan ketersediaan obat yang lengkap terdapat 52\% responden menyatakan puas dan sangat puas. Pernyataan ketersediaan sumber informasi kesehatan (poster, brosur) terdapat 54\% responden menyatakan puas dan sangat puas. Berdasarkan data tersebut mayoritas konsumen merasakan puas terhadap semua pernyataan pada dimensi tangible yang berarti petetugas apotek di Apotek Ganesha Farma Kabupaten Lamongan telah melakukan pelayanan dengan baik, akan tetapi masih terdapat $10 \%$ konsumen menyatakan tidak puas terhadap pernyataan Kebersihan di lingkungan Apotek. Hal ini disebabkan karena lokasi apotek yang jaraknya berdekatan dengan pasar, secara tidak langsung hal ini menyebabkan adanya bau yang tidak mengenakan konsumen saat beli obat di apotek, kemudian adanya sampah-sampah dari pasar di depan jalanan apotek yang dirasa menganggu kenyamanan konsumen. Menurut Kotler (2005), bahwa penampilan fisik, peralatan, serta personil yang mencakup kebersihan, kerapian dan kenyamanan ruangan, penilaian eksterior dan interior, kelengkapan, kesiapan dan kebersihan alat-alat yang dipakai, dan kerapian dan kebersihan penampilan petugas terhadap pelayanan kesehatan pada pasien akan berdapampak pada tingkat kepuasan pasien [27]. 


\subsection{Gambaran Tingkat Kepuasan Konsumen Apotek Terhadap Pelayanan Kefarmasian Di Apotek Ganesha Farma Kabupaten Lamongan}

\subsubsection{Dimensi kehandalan (reliability)}

Berdasarkan data pada tabel 18, konsumen apotek dikatakan puas pada semua item pernyataan dimensi kehandalan (reliability) yang berarti persepsi konsumen apotek terhadap pelayanan pada dimensi ini di Apotek Ganesha Farma Kabupaten Lamongan telah sesuai dengan harapan yang diinginkan, akan tetapi petugas apotek memberi informasi tentang efek samping obat mendapatkan nilai kepuasan terendah dengan presentase $67 \%$. Menurut Ahaditomo (2004) permasalahan terkait efek samping obat tidak bisa dipandang sebelah mata karena dapat menimbulkan beberapa dampak negatif bagi konsumen baik dari segi psikologi, ekonomi, dan juga keberhasilan terapi [25].

Berdasarkan data harapan dan kenyataan pada dimensi kehandalan (reliability), nilai kenyataan pada masing-masing item pernyataan pada dimensi ini lebih rendah dari pada nilai harapan. Namun pada hasil akhir atau presentase tingkat kepuasan pada dimensi ini menunjukkan hasil puas.

\subsubsection{Dimensi daya tanggap (responsivenesss)}

Berdasarkan data pada tabel 19, konsumen apotek dikatakan puas pada semua item pernyataan dimensi ketanggapan (responsivenesss) yang berarti persepsi konsumen apotek terhadap pelayanan pada dimensi ini di Apotek Ganesha Farma Kabupaten Lamongan telah sesui dengan harapan yang diinginkan, akan tetapi petugas apotek harus meningkatkan pelayanan pada pernyataan petugas apotek mendengarkan keluhan konsumen dengan seksama karena mendapatkan nilai kepuasan terendah dengan presentase 68,4\%. Menurut Aprilia (2008) keluhan-keluhan yang berasal dari pasien harus diperhatikan dan ditanggapi oleh instalasi farmasi yan terkait, hal ini dapat menjadi masukan yang positif untuk membantu dalam meningkatkan kualitas pelayanan kesehatan [21].

Berdasarkan data harapan dan kenyataan pada dimensi ketanggapan (responsivenesss), nilai kenyataan pada masingmasing item pernyataan pada dimensi ini lebih rendah dari pada nilai harapan. Namun pada hasil akhir atau presentase tingkat kepuasan pada dimensi ini menunjukkan hasil puas.

\subsubsection{Dimensi jaminan (assurance)}

Berdasarkan data pada tabel 20, konsumen apotek dikatakan puas pada semua item pernyataan dimensi jaminan (assurance) yang berarti persepsi konsumen apotek terhadap pelayanan pada dimensi ini di Apotek Ganesha Farma
Kabupaten Lamongan telah sesuai dengan harapan yang diinginkan, akan tetapi petugas harus meningkatkan jaminan obat yang diterima konsumen apotek dalam kondisi baik dan benar karena mendapatkan nilai terendah dengan presentase $68,4 \%$. Berdasarkan data harapan dan kenyataan pada dimensi jaminan (assurance), nilai kenyataan pada masing-masing item pernyataan pada dimensi ini lebih rendah dari pada nilai harapan. Namun pada hasil akhir atau presentase tingkat kepuasan pada dimensi ini menunjukkan hasil puas.

\subsubsection{Dimensi kepedulian (empathy)}

Berdasarkan data pada tabel 21, konsumen apotek dikatakan puas pada semua item pernyataan dimensi kepedulian (empathy) yang berarti persepsi pasien terhadap pelayanan pada dimensi ini di Apotek Ganesha Farma Kabupaten Lamongan telah sesuai dengan harapan yang diinginkan, akan tetapi petugas harus meningkatkan pelayanan pada pernyataan petugas apotek memberikan perhatian yang tulus demi kesehatan konsumen dengan nilai kepuasan 69,2\%. Menurut Aprilia (2008) keluhan yang berasal dari pasien harus diperhatikan dan ditanggapi oleh instalasi farmasi yang terkait, hal ini dapat menjadikan masukan yang positif untuk membantu dalam meningkatkan kualitas pelayanan kesehatan [21].

Berdasarkan data harapan dan kenyataan pada dimensi kepedulian (empathy), nilai kenyataan pada masingmasing item pernyataan pada dimensi ini lebih rendah dari pada nilai harapan. Namun pada hasil akhir atau presentase tingkat kepuasan pada dimensi ini menunjukkan hasil puas.

\subsubsection{Dimensi bukti fisik (tangible)}

Berdasarkan data pada tabel 22, konsumen dikatakan puas pada semua item pernyataan dimensi bukti fisik (Tangibel) yang berarti persepsi konsumen apotek terhadap pelayanan pada dimensi ini di Apotek Ganesha Farma telah sesuai dengan harapan yang diinginkan, akan tetapi petugas harus meningkatkan pelayanan pada pernyataan petugas apotek berpenampilan rapi dan bersih karena pada pernyataan ini presentase kepuasan 68\%. Menurut Kotler (2005), kerapihan dan kebersihan penampilan petugas terhadap pelayanan kesehatan terhadap pasien akan berdampak pada tingkat kepuasan pasien [27].

Berdasarkan data harapan dan kenyataan pada dimensi bukti fisik (Tangibel), nilai kenyataan pada masingmasing item pernyataan pada dimensi ini lebih rendah dari pada nilai harapan. Namun pada hasil akhir atau presentase tingkat kepuasan pada dimensi ini menunjukkan hasil puas.

\subsection{Tingkat Kepuasan Total Konsumen Apotek Terhadap Pelayanan Kefarmasian di Apotek Ganesha Farma}




\section{Kabupaten Lamongan Menggunakan Metode Customer Satisfiaction Indeks (CSI)}

Berdasarkan data pada tabel 23, didapatkan hasil nilai Customer Satisfaction Index (CSI) pada dimensi kehandalan sebesar 70,8\% yang berarti puas. Berdasarkan hasil tersebut mayoritas konsumen merasakan puas pada dimensi kehandalan terhadap pelayanan kefarmasian di Apotek Ganesha Farma. Menurut penelitian Setianingrum, dkk (2011) menyatakan bahwa tingkat kepuasan konsumen apotek di Kabupaten Banjarnegara pada dimensi reliability yaitu puas dengan nilai Customer Satisfaction Index (CSI) 71,89 [33]. Menurut penelitian yang dilakukan oleh Putriana (2017) menyatakan bahwa aspek konseling seperti cara penggunaan obat dan efek samping obat harus disampaikan kepada pasien untuk mencegah adanya kesalahan penggunaan obat, sehingga dapat meningkatkan kualitas hidup pasien dan kepuasan terhadap pelayanan [7].

Pada dimensi ketanggapan (responsiveness) didapatkan nilai Customer Satisfaction Index yaitu 68,8\% yang berarti puas. Menurut penelitian yang dilakukakan Yulia,dkk (2016) menyatakan bahwa hasil analisa dimensi responsivenesss, tingkat kepuasan pasien adalah puas dengan nilai Customer Satisfaction Index (CSI) 74\% [34]. Menurut penelitian yang dilakukan oleh Monika, Chreisye dan Paul (2015) dimensi ketanggapan memiliki nilai harapan yang tinggi dan memiliki hubungan yang signifikan terhadap kepuasan pasien [6].

Pada dimensi jaminan (assurance) didapatkan nilai Customer Satisfaction Index yaitu 69\% yang berarti puas. Menurut penelitian yang dilakukan oleh Yulia,dkk (2016) menyatakan bahwa hasil analisa dimensi assurance, tingkat kepuasan pasien adalah puas dengan nilai Customer Satisfaction Index (CSI) 78,6 \% [34]. Menurut Kotler (2005) jaminan keamanan dan kepercayaan dalam pelayanan akan berdampak kepada tingkat kepuasan konsumen [27].

Pada dimensi kepedulian (empathy) didapatkan nilai Customer Satisfaction Index yaitu 69,8\% yang berarti puas. Menurut penelitian yang dilakukan oleh Akhmad, dkk (2019) nilai Customer Satisfaction Index (CSI) pada dimensi empathy masuk dalam kategori sangat puas dengan presentase 87,83\% [35]. Menurut Karl (2005) interaksi langsung yang dilakukan oleh petugas dalam melayani pelanggan harus dengan tulus dan penuh kepedulian karena dengan begitu dapat meningkatkan kepuasan pelanggan [28].

Tabel 1. Hasil Uji Validitas Kuesioner Tingkat Harapan
Pada dimensi bukti fisik (tangible) didapatkan nilai Customer Satisfaction Index yaitu $69,4 \%$ yang berarti puas. Menurut penelitian yang dilakukan oleh Setianingrum dan Sudarso (2011) menyatakan bahwa hasil analisa dimensi Tangible, tingkat kepuasan pasien adalah puas dengan nilai Customer Satisfaction Index (CSI) 77,04\%. Menurut penelitian yang dilakukan Aprillya, (2013) menyatakan bahwa dimensi tangible mempunyai pegaruh positif terhadap kepuasan, apabila pelayanan memiliki aspek tangible yang bagus maka secara simultan akan meningkatkan kepuasan pasien [36].

Setelah diketahui hasil kepuasan konsumen pada tiaptiap dimensi maka dapat diketahui bahwasanya dimensi reliability memiliki presentase nilai CSI tertinggi yakni 70,8\% karena sebagian besar konsumen yang datang ke Apotek mendapatkan penjelasan terkait informasi obat yang akan digunakan baik dari segi (cara pakai, efek samping,dll) hal ini membuat konsumen merasa puas terhadap pelayanan pada dimensi ini. Dan dimensi responsiveness memiliki presentase nilai CSI terendah yakni $68,8 \%$ dikarenakan sebagian besar konsumen menganggap bahwa pelayanan yang diberikan oleh petugas apotek kurang ramah, tidak selalu standy dalam melayani konsumen saat datang dan terkesan tidak memperdulikan keluhan konsumen, sehingga konsumen merasa tidak puas pada dimensi responsiveness.

Hasil kepuasan konsumen terhadap pelayanan kefarmasian secara total yaitu $69,56 \%$, dimana nilai tersebut dalam tabel nilai Customer Satisfaction Index berada pada rentang 66\% - 80,99\% yang berarti secara keseluruhan konsumen apotek telah merasa puas dengan pelayanan kefarmasian yang diberikan di Apotek Ganesha Farma Kabupaten Lamongan. Menurut penelitian yang dilakukan Setianingrum (2011) menyatakan bahwa tingkat kepuasan konsumen di Apotek Kabupaten Banjarnergara menunjukkan nilai CSI (Customer Satifaction Index) 69,5\% yang berarti puas [33]. Menurut penelitian yang dilakukakan oleh Putri (2017) menunjukkan tingkat kepuasan pasien terhadap pelayanan kefarmasian memiliki pengaruh positif terhadap loyalitas pasien, sehingga semakin tinggi tingkat kepuasan semakin loyal pasien [7] 


\begin{tabular}{|c|c|c|c|c|}
\hline Pernyataan & Item & r hitung & r tabel & Kesimpulan \\
\hline \multirow[t]{6}{*}{ Kehandalan } & 1. & 0,792 & 0,361 & Valid \\
\hline & 2. & 0,680 & 0,361 & Valid \\
\hline & 3. & 0,630 & 0,361 & Valid \\
\hline & 4. & 0,468 & 0,361 & Valid \\
\hline & 5. & 0,721 & 0,361 & Valid \\
\hline & 6. & 0,806 & 0,361 & Valid \\
\hline \multirow[t]{3}{*}{ Ketanggapan } & 7. & 0,749 & 0,361 & Valid \\
\hline & 8. & 0,765 & 0,361 & Valid \\
\hline & 9. & 0,726 & 0,361 & Valid \\
\hline \multirow[t]{2}{*}{ Jaminan } & 10. & 0,608 & 0,361 & Valid \\
\hline & 11. & 0,879 & 0,361 & Valid \\
\hline \multirow[t]{3}{*}{ Kepedulian } & 12. & 0,856 & 0,361 & Valid \\
\hline & 13. & 0,808 & 0,361 & Valid \\
\hline & 14. & 0,707 & 0,361 & Valid \\
\hline \multirow[t]{3}{*}{ Bukti Fisik } & 15. & 0,746 & 0,361 & Valid \\
\hline & 17. & 0,789 & 0,361 & Valid \\
\hline & 18. & 0,731 & 0,361 & Valid \\
\hline
\end{tabular}

Tabel 2. Hasil Validitas Kuesioner Tingkat Kenyataan

\begin{tabular}{|c|c|c|c|c|}
\hline Pernyataan & Item & r hitung & $r$ tabel & Kesimpulan \\
\hline \multirow[t]{6}{*}{ Kehandalan } & 1. & 0,605 & 0,361 & Valid \\
\hline & 2. & 0,756 & 0,361 & Valid \\
\hline & 3. & 0,725 & 0,361 & Valid \\
\hline & 4. & 0,595 & 0,361 & Valid \\
\hline & 5. & 0,680 & 0,361 & Valid \\
\hline & 6. & 0,873 & 0,361 & Valid \\
\hline \multirow[t]{2}{*}{ Ketanggapan } & 7. & 0,766 & 0,361 & Valid \\
\hline & 9. & 0,763 & 0,361 & Valid \\
\hline \multirow[t]{2}{*}{ Jaminan } & 10. & 0,876 & 0,361 & Valid \\
\hline & 11. & 0,786 & 0,361 & Valid \\
\hline \multirow[t]{3}{*}{ Kepedulian } & 12. & 0,708 & 0,361 & Valid \\
\hline & 13. & 0,769 & 0,361 & Valid \\
\hline & 14. & 0,764 & 0,361 & Valid \\
\hline \multirow[t]{3}{*}{ Bukti Fisik } & 15. & 0,791 & 0,361 & Valid \\
\hline & 17. & 0,747 & 0,361 & Valid \\
\hline & 18. & 0,832 & 0,361 & Valid \\
\hline
\end{tabular}

Tabel 3. Hasil Uji Reliabilias Kuesioner Tingkat Harapan Semua Variabel

\begin{tabular}{cc}
\hline \multicolumn{2}{c}{ Reliability Statistics } \\
\hline Cronbach's Alpha & N of Items \\
\hline, 948 & 18 \\
\hline
\end{tabular}

Tabel 4. Hasil Uji Reliabilias Kuesioner Tingkat Kenyataan Semua Variabel

\begin{tabular}{cc}
\hline \multicolumn{2}{c}{ Reliability Statistics } \\
\hline Cronbach's Alpha & N of Items \\
\hline, 958 & 18 \\
\hline
\end{tabular}

Tabel 5. Karakteristik Responden Berdasarkan Jenis Kelamin

\begin{tabular}{lccc}
\hline & & Jenis Kelamin & Presentase \\
\hline Kategori & Jumlah Responden & $52 \%$ \\
Perempuan & & 52 & $48 \%$ \\
\hline
\end{tabular}

Tabel 6. Karakteristik Responden Berdasarkan Umur

$\begin{array}{cc}\text { Umur } & \text { Presentase (\%) } \\ 17-25 & 26 \%\end{array}$




$\begin{array}{ll}26-35 & 23 \% \\ 36-45 & 41 \%\end{array}$

Tabel 7. Karakteristik Responden Berdasarkan Pekerjaan

\begin{tabular}{cc} 
Pekerjaan & Presentase (\%) \\
Petani & 23 \\
Mahasiswi/Mahasiswa & 20 \\
Guru & 19 \\
Nelayan & 12 \\
Ibu Rumah Tangga & 12 \\
Pedagang & 8 \\
Siswi/Siswa SMA & 6 \\
\hline
\end{tabular}

Tabel 8. Hasil Perhitungan Tingkat Kenyataan pada Dimensi Reliability

\begin{tabular}{|c|c|c|c|c|c|c|c|c|c|c|c|}
\hline \multirow{3}{*}{ No. } & \multirow{3}{*}{ Pernyataan } & \multicolumn{10}{|c|}{ Jawaban } \\
\hline & & \multicolumn{2}{|c|}{$\begin{array}{l}\text { Sangat } \\
\text { tidak puas }\end{array}$} & \multicolumn{2}{|c|}{ Tidak puas } & \multicolumn{2}{|c|}{$\begin{array}{l}\text { Cukup } \\
\text { puas }\end{array}$} & \multicolumn{2}{|c|}{ Puas } & \multicolumn{2}{|c|}{$\begin{array}{c}\text { Sangat } \\
\text { puas }\end{array}$} \\
\hline & & $\sum$ & $\%$ & $\sum$ & $\%$ & $\Sigma$ & $\%$ & $\Sigma$ & $\%$ & $\Sigma$ & $\%$ \\
\hline 1. & $\begin{array}{l}\text { Petugas Apotek memberikan informasi terkait nama, } \\
\text { kandungan, jumlah, dan dosis obat }\end{array}$ & 0 & 0 & 5 & $5 \%$ & 39 & $39 \%$ & 43 & $43 \%$ & 13 & $13 \%$ \\
\hline 2. & $\begin{array}{l}\text { Petugas Apotek memberi informasi terkait cara } \\
\text { penggunaan obat }\end{array}$ & 0 & 0 & 4 & $4 \%$ & 29 & $29 \%$ & 57 & $57 \%$ & 10 & $10 \%$ \\
\hline 3. & $\begin{array}{l}\text { Petugas Apotek memberi informasi terkait aturan } \\
\text { pakai obat }\end{array}$ & 0 & 0 & 9 & $9 \%$ & 53 & $53 \%$ & 32 & $32 \%$ & 6 & $6 \%$ \\
\hline 4. & $\begin{array}{l}\text { Petugas Apotek memberi informasi tentang efek } \\
\text { samping obat }\end{array}$ & 0 & 0 & 11 & $11 \%$ & 27 & $27 \%$ & 54 & $54 \%$ & 8 & $8 \%$ \\
\hline 5. & $\begin{array}{l}\text { Petugas Apotek menjelaskan informasi obat dengan } \\
\text { bahasa yang mudah dimengeti }\end{array}$ & 0 & 0 & 9 & $9 \%$ & 47 & $47 \%$ & 36 & $36 \%$ & 8 & $8 \%$ \\
\hline 6. & $\begin{array}{l}\text { Petugas Apotek memberikan kesempatan kepada } \\
\text { konsumen untuk menceritakan keluhannya }\end{array}$ & 0 & 0 & 9 & $9 \%$ & 29 & $29 \%$ & 52 & $52 \%$ & 10 & $10 \%$ \\
\hline
\end{tabular}

Tabel 9. Hasil Perhitungan Tingkat Kenyataan pada Dimensi Responsiveness

\begin{tabular}{|c|c|c|c|c|c|c|c|c|c|c|c|}
\hline \multirow{3}{*}{ No. } & \multirow{3}{*}{ Pernyataan } & \multicolumn{10}{|c|}{ Jawaban } \\
\hline & & \multicolumn{2}{|c|}{$\begin{array}{c}\text { Sangat } \\
\text { tidak puas }\end{array}$} & \multicolumn{2}{|c|}{$\begin{array}{l}\text { Tidak } \\
\text { puas }\end{array}$} & \multicolumn{2}{|c|}{ Cukup puas } & \multicolumn{2}{|c|}{ Puas } & \multicolumn{2}{|c|}{$\begin{array}{c}\text { Sangat } \\
\text { puas }\end{array}$} \\
\hline & & $\sum$ & $\%$ & $\sum$ & $\%$ & $\sum$ & $\%$ & $\sum$ & $\%$ & $\sum$ & $\%$ \\
\hline 1. & Petugas Apotek selalu siap melayani konsumen & 0 & 0 & 7 & $7 \%$ & 49 & $49 \%$ & 35 & $35 \%$ & 9 & $9 \%$ \\
\hline 2. & $\begin{array}{c}\text { Petugas Apotek mendengarkan keluhan konsumen } \\
\text { dengan seksama. }\end{array}$ & 0 & 0 & 12 & $12 \%$ & 40 & $40 \%$ & 42 & $42 \%$ & 6 & $6 \%$ \\
\hline 3. & $\begin{array}{l}\text { Petugas Apotek menanggapi pertanyaan konsumen } \\
\text { terkait obat-obatan yang didapat }\end{array}$ & 0 & 0 & 11 & $11 \%$ & 40 & $40 \%$ & 43 & $43 \%$ & 6 & $6 \%$ \\
\hline
\end{tabular}

Tabel 10. Hasil Perhitungan Tingkat Kenyataan pada Dimensi Assurance

\begin{tabular}{|c|c|c|c|c|c|c|c|c|c|c|c|}
\hline \multirow{3}{*}{ No. } & \multirow{3}{*}{ Pernyataan } & \multicolumn{10}{|c|}{ Jawaban } \\
\hline & & \multicolumn{2}{|c|}{$\begin{array}{c}\text { Sangat } \\
\text { tidak puas }\end{array}$} & \multicolumn{2}{|c|}{$\begin{array}{l}\text { Tidak } \\
\text { puas }\end{array}$} & \multicolumn{2}{|c|}{$\begin{array}{c}\text { Cukup } \\
\text { puas }\end{array}$} & \multicolumn{2}{|c|}{ Puas } & \multicolumn{2}{|c|}{$\begin{array}{c}\text { Sangat } \\
\text { puas }\end{array}$} \\
\hline & & $\sum$ & $\%$ & $\sum$ & $\%$ & $\sum$ & $\%$ & $\sum$ & $\%$ & $\sum$ & $\%$ \\
\hline 1. & $\begin{array}{l}\text { Obat yang diterima konsumen dalam kondisi baik dan } \\
\text { benar }\end{array}$ & 0 & 0 & 13 & $13 \%$ & 38 & $38 \%$ & 43 & $43 \%$ & 6 & $6 \%$ \\
\hline 2. & $\begin{array}{l}\text { Petugas Apotek mempunyai pengetahuan dan } \\
\text { keterampilan yang baik dalam bekerja }\end{array}$ & 0 & 0 & 6 & $6 \%$ & 43 & $43 \%$ & 45 & $45 \%$ & 6 & $6 \%$ \\
\hline
\end{tabular}

Tabel 11. Hasil Perhitungan Tingkat Kenyataan pada Dimensi Empathy

\begin{tabular}{lccccc}
\hline & & \multicolumn{3}{c}{ Jawaban } \\
\cline { 3 - 6 } No. & Pernyataan & $\begin{array}{c}\text { Sangat } \\
\text { tidak } \\
\text { puas }\end{array}$ & Tidak puas & Cukup puas & $\begin{array}{c}\text { Puas } \\
\begin{array}{c}\text { Sangat } \\
\text { puas }\end{array}\end{array}$ \\
\hline
\end{tabular}




\begin{tabular}{|c|c|c|c|c|c|c|c|c|c|c|c|}
\hline & $\sum$ & $\%$ & $\sum$ & $\%$ & $\sum$ & $\%$ & $\sum$ & $\%$ & $\sum$ & $\%$ \\
\hline 1. & $\begin{array}{l}\text { Petugas Apotek memberikan perhatian yang tulus } \\
\text { demi kesehatan konsumen }\end{array}$ & 0 & 0 & 11 & $11 \%$ & 38 & $38 \%$ & 45 & $45 \%$ & 6 & $6 \%$ \\
\hline 2. & $\begin{array}{l}\text { Petugas Apotek mendengarkan pertanyaan dan } \\
\text { keluhan konsumen dengan sabar }\end{array}$ & 0 & 0 & 7 & $7 \%$ & 41 & $41 \%$ & 47 & $47 \%$ & 5 & $5 \%$ \\
\hline 3. & $\begin{array}{l}\text { Petugas Apotek ramah dan sopan melayani } \\
\text { konsumen }\end{array}$ & 0 & 0 & 4 & $4 \%$ & 44 & $44 \%$ & 46 & $46 \%$ & 6 & $6 \%$ \\
\hline
\end{tabular}

Tabel 12. Hasil Perhitungan Tingkat Kenyataan pada Dimensi Tangibel

No.

\section{Pernyataan}

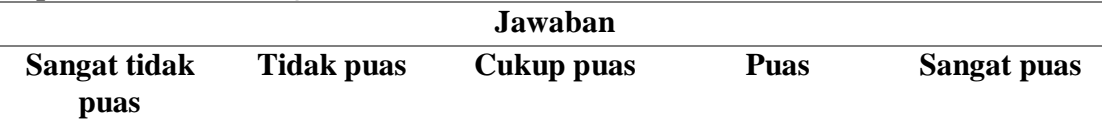

\begin{tabular}{|c|c|c|c|c|c|c|c|c|c|c|c|}
\hline & & $\sum$ & $\%$ & $\sum$ & $\%$ & $\sum$ & $\%$ & $\sum$ & $\%$ & $\sum$ & $\%$ \\
\hline 1. & Kebersihan di lingkungan Apotek & 1 & $1 \%$ & 9 & $9 \%$ & 35 & $35 \%$ & 50 & $50 \%$ & 5 & $5 \%$ \\
\hline 2. & $\begin{array}{l}\text { Petugas Apotek berpenampilan rapi } \\
\text { dan bersih }\end{array}$ & 1 & $1 \%$ & 8 & $8 \%$ & 45 & $45 \%$ & 42 & $42 \%$ & 4 & $4 \%$ \\
\hline 3. & Ketersediaan obat yang lengkap & 0 & 0 & 8 & $8 \%$ & 40 & $40 \%$ & 46 & $46 \%$ & 6 & $6 \%$ \\
\hline 4. & $\begin{array}{l}\text { Ketersediaan sumber informasi } \\
\text { kesehatan (poster, brosur) }\end{array}$ & 0 & 0 & 2 & $2 \%$ & 44 & $44 \%$ & 48 & $48 \%$ & 6 & $6 \%$ \\
\hline
\end{tabular}

Tabel 13. Hasil Perhitungan Tingkat Kepuasan pada Dimensi Reliability

\begin{tabular}{cccccc}
\hline No. & Pernyataan & MIS & MSS & Tingkat Kepuasan Pernyataan & Tingkat Kepuasan Dimensi \\
\hline 1. & Reliability 1 & 4,55 & 3,64 & $72,8 \%$ & \\
\hline 2. & Reliability 2 & 4,69 & 3,73 & $64,6 \%$ & \\
\hline 3. & Reliability 3 & 4,66 & 3,35 & $71,8 \%$ & $70,8 \%$ \\
\hline 4. & Reliability 4 & 4,54 & 3,59 & $68,6 \%$ & \\
\hline $\mathbf{5 .}$ & Reliability 5 & 4,58 & 3,43 & $72,6 \%$ & \\
\hline 6. & Reliability 6 & 4,51 & 3,63 &
\end{tabular}

Tabel 14. Hasil Perhitungan Tingkat Kepuasan pada Dimensi Responsivenessss

\begin{tabular}{cccccc}
\hline No. & Pernyataan & MIS & MSS & Tingkat Kepuasan Pernyataan & $\begin{array}{c}\text { Tingkat Kepuasan } \\
\text { Dimensi }\end{array}$ \\
\hline 1. & Responsivenesss 1 & 4,52 & 3,46 & $69,2 \%$ & $68,8 \%$ \\
2. & Responsivenesss 2 & 4,54 & 3,42 & $68,4 \%$ & $68,8 \%$ \\
3. & Responsivenesss 3 & 4,57 & 3,44 & 6 & \\
\hline
\end{tabular}

Tabel 15. Hasil Perhitungan Tingkat Kepuasan pada Dimensi Assurance

\begin{tabular}{cccccc}
\hline No. & Pernyataan & MIS & MSS & Tingkat Kepuasan Pernyataan & Tingkat Kepuasan Dimensi \\
\hline 1. & Assurance 1 & 4,58 & 3,42 & $68,4 \%$ & $69 \%$ \\
2. & Assurance 2 & 4,6 & 3,51 & $70,2 \%$ & \\
\hline
\end{tabular}

Tabel 16. Hasil Perhitungan Tingkat Kepuasan pada Dimensi Empathy

\begin{tabular}{cccccc}
\hline No. & Pernyataan & MIS & MSS & Tingkat Kepuasan Pernyataan & Tingkat Kepuasan Dimensi \\
\hline 1. & Empathy 1 & 4,6 & 3,46 & $69,2 \%$ & $69,8 \%$ \\
2. & Empathy 2 & 4,67 & 3,5 & $70 \%$ & \\
3. & Empathy 3 & 4,55 & 3,54 & $70,8 \%$ & \\
\hline
\end{tabular}

Tabel 17. Hasil Perhitungan Tingkat Kepuasan pada Dimensi Tangible

\begin{tabular}{cccccc}
\hline No. & Pernyataan & MIS & MSS & Tingkat Kepuasan Pernyataan & Tingkat Kepuasan Dimensi \\
\hline 1. & Tangible 1 & 4,5 & 3,49 & $69,8 \%$ & \\
2. & Tangible 2 & 4,42 & 3,4 & $68 \%$ & $69,4 \%$ \\
3. & Tangible 3 & 4,38 & 3,5 & $70 \%$ & \\
4. & Tangible 4 & 4,23 & 3,58 & $71,6 \%$ & \\
\hline
\end{tabular}

Tabel 18. Hasil Perhitungan Tingkat Kepuasan dengan Customer Satisfaction Index (CSI)

\begin{tabular}{cccccccc}
\hline No. & Dimensi & MSS & MIS & WF (\%) & WS & CSI (\%) & Tingkat kepuasaan \\
\hline 1. & Kehandalan (reliability) & 21,37 & 27,53 & 33,70 & 7,05 & 70,8 & Puas \\
2. & Ketanggapan (responsivenesss) & 10,32 & 13,63 & 16,68 & 1,65 & 68,8 & Puas \\
3. & Jaminan (assurance) & 6,93 & 9,18 & 11,23 & 0,76 & 69 & Puas
\end{tabular}




5.

Kepedulian (empathy)

10,5

13,82

16,91

1,68

2,93

69,8

69,4

69,56

Puas

\section{Kesimpulan}

Berdasarkan penelitian yang telah dilakukan bahwa tingkat kepuasan konsumen apotek terhadap pelayanan kefaramasian di Apotek Ganesha Farma Kabupaten Lamongan dengan menggunakan metode Customer Satisfiaction Indeks (CSI) didapatkan nilai CSI pada dimensi kehandalan (reliability) 70,8\% yang berarti puas, dimensi ketanggapan (responsiveness) 68,8\% yang berarti puas, dimensi jaminan (assurance) $69 \%$ yang berarti puas, dimensi kepedulian (empathy) 69,8\% yang berarti puas, dan pada dimensi bukti fisik (tangible) 69,4\% yang berarti puas. Secara keseluruhan tingkat kepuasan konsumen apotek terhadap pelayanan kefaramasian di Apotek Ganesha Farma Kabupaten Lamongan dengan menggunakan metode Customer Satisfiaction Indeks (CSI) didapatkan nilai yakni 69,56\% yang menunjukkan bahwa secara keseluruhan konsumen apotek merasakan puas terhadap pelayanan yang diberikan.

\section{Ucapan Terima Kasih}

Ucapan terima kasih kepada Bapak Ganef selaku pemilik Apotek Ganesha Farma yang telah memberikan izin penelitan kepada penulis sehingga penelitian bisa dilakukan dengan lancar.

\section{Daftar Pustaka}

[1] [Depkes RI] Peraturan Menteri Kesehatan Repubilk Indonesia Nomor 73 tahun 2016 tentang Standar Pelayanan Kefarmasian di Apotek. Jakarta: Departemen Kesehatan RI.

[2] [Depkes RI] Keputusan Menteri Kesehatan Republik Indonesia Nomor 128 Tahun 2004 Tentang Kebijakan Dasar Pusat Kesehatan Masyarakat. Jakarta: Departemen Kesehatan RI.

[3] Bustami, M. S. 2011. Penjaminan Mutu Pelayanan Kesehatan \& Akseptabilitasnya. Jakarta: Erlangga.

[4] Pohan, I.S. 2007. Jaminan Mutu Layaan Kesehatan: Dasardasar Pengertian dan Penerapan. Jakarta: EGC. Hal. 11-20.

[5] Harianto. 2005. Manajemen Mutu Pelayanan Kesehatan. Surabaya: Airlangga University.

[6] Monika,K., Chreisye, K. F., Mandagi, Paul A.T dan Kawatu. 2015. Hubungan antara Mutu Pelayanan Kefarmasian dengan Kepuasan Pasien Rawat Jalan di Puskesmas Teling Atas Kota Manado. Jurnal Ilmiah Farmasi. UNSRAT volume 4, nomer 4.

[7] Putri, D.R. 2017. Pengaruh Kualitas Pelayanan Kefarmasian Terhadap Kepuasan, Kepercayaan \& Loyalitas Konsumen Apotek. Indonesian journal for health. Vol.1. No.1.

[8] Parasuraman, A., Berry, L.L., dan Zeithaml, A.V. 1988. "SERVQUAL: A Multiple Item Scale for Measuring
Consumer Perceptions of Service Quality", Journal of Retailing, Vol. 64, No. 1, Spring, 12-40.

[9] Dewi, N. P. A. T., Dewantara, I. G. N. A., dan Setyawan, E. I. 2014. Pengaruh Mutu Pelayanan Terhahap Tingkat Kepuasan Konsumen di Apotek Non Praktek Dokter di Kuta Utara. Jurnal Farmasi Udayana. Volume 3, Nomer 1.

[10] Fithria, R, F., dan Umi, S. 2014. Perbandingan Kualitas Pelayanan Instalasi Farmasi Pasien Bpjs Rawat Jalan Rumah Sakit Pemerintah Dan Swasta Kota Semarang. Univ ersitas Wahid Hasyim Semarang.

[11] Yuniar. Y., Rini S. H. 2016. Kepuasan Pasien Peserta Program Jaminan Kesehatan Nasional terhadap Pelayanan Kefarmasian di Apotek. Jurnal Kefarmasian Indonesia.Vol.6 No.1.

[12] Harijono, H., dan Bobby.O.P.S. 2011. Upaya Peningkatan Kualitas Layanan Farmasi Rsk. St Vincentius A Paulo Surabaya Dengan Menggunakan Metode SERVQUAL Dan QFD. Surabaya: ITS

[13] Pareraway, DC. 2016. Analisis Kepuasan Pasien Rawat Jalan dalam Pelayanan Kefarmasian di Instaliasi Farmasi RSUP Prof. Dr. R. D. Kandou Manado. Program Studi Farmasi FMIPA UNSRAT Manado. PHARMACON Jurnal Ilmiah Farmasi UNSRAT Vol. 5 No. 4.

[14] Ghozali, I. 2005. Aplikasi Analisis Multivariate dengan SPSS. Semarang: Badan Penerbit UNDIP.

[15] [Dinas Kependudukan dan Catatan Sipil] Demografi Pasien 2018: Lamongan: Badan Pusat Statistik Kabupaten Lamongan.

[16] [Dinas Kesehatan Kabupaten Lamongan] Profil Kesehatan Kabupaten Lamongan Tahun 2019. Lamongan: Dinas Kesehatan Kabupaten Lamongan.

[17] Pangala, Angelia. 2014. Analisis Kualitas Pelayanan Terhadap Tingkat Kepuasan Pelanggan Pada Apotek Didesa Catur Tunggal depok.[Skripsi].Universitas Sanata Dharma

[18] Misnaniarti, 2017. Analisis Situasi Penduduk Lanjut Usia Dan Upaya Peningkatan Kesejahteraan Sosial Di Indonesia. Jurnal Ilmu Kesehatan Masyarakat. Volume. 8, No. 2.

[19] Supranto, J. 2002. Metode Riset dan Aplikasinya. Jakarta: PT. Rineka Cipta.

[20] Priyanto, A, Moeslich, H dan Didik, S. 2010. Pelaksanaan Penyimpanan Obat Dan Pelayanan Informasi Obat Kepada Pasien Di Puskesmas di Kota Purwokerto. PHARMACY, Vol.07 No. 03 Desember 2010

[21] Aprilia, E, H., 2008. Tingkat Kepuasan Pasien Rawat Jalan Terhadap Kualitas Pelayanan Instalasi Farmasi Rumah Sakit Umum Kakabupaten Sragen. [Skripsi], Fakultas Farmasi. Univeristas Muhammadiyah Surakarta: Surakarta.

[22] Aslam, M., Tan, C.K., dan Prayitno, A., 2003, Farmasi Klinis (Clinical Pharmacy), Penerbit PT Elek Media Komputindo.

[23] Hartini, Y.S, dan Sulasmono, 2006, Apotek: Ulasan Beserta Naskah Peraturan Perundang-undangan Terkait Apotek, Universitas Sanata Dharma: Yogyakarta. 
[24] [Depkes RI] Standar Pelayanan Kefarmasian di Apotek. Keputusan Menteri Kesehatan

Nomor.1027/Menkes/SK/IX/2004. Jakarta: Departemen Kesehatan RI.

[25] Ahaditomo.2004.Standar Kompotensi Farmasis Indonesia. Jakarta ISFI

[26] Mayang,F,S., dan Suprianto. 2017. Tingkat Kepuasan Pasien Terhadap Pelayanan Kefarmasian Di Apotek Global Medan Patient Satisfaction Level of Pharmaceutical Serviices In Global Pharmacy Medan. Jurnal Dunia Farmasi Volume 1, No.3.

[27] Kotler, Philp. 2005. Manajemen Pemasaran. Jakarta: Indeks

[28] Karl. 2005. Relationship Benefits in An Internet Environment. Journal of Managing Service Quality, Vol. 15. pp. 426-436

[29] Wahyuni, H.C dan Sulistiyowati, W. 2015. Penentuan Prioritas Perbaikan Kualitas Layanan Kesehatan Dengan Metode Servqual. JEMIS. Sidoarjo: Universitas Muhammadiyah Sidoarjo. Volume. 3 Nomor. 1: 6.

[30] Fitri, E.T.Y dan Setya.H. 2013. Analisis Kepuasan Berdasarkan Persepsi Dan Harapan Pasien di Puskesmas Medokan Ayu Surabaya. Jurnal Administrasi Kesehatan Indonesia, Vol. 1 No. 1.

[31] Sholihah,A.I. 2019 Analisis Kepuasan Pasien Raawat Jalan Terhadap Pelayanan Kefarmasian Di Dr. Moedjito Dwijosiswojo Kabupaten Jombang.[Skripsi].Malang. Uin Maulana Malik Ibrahim

[32] Wijono, D. 2000. Menejemen Mutu Pelayanan Kesehatan Teori, Dtrategi, Dan Aplkasi. Surabaya: Airlangga University Press.

[33] Setianingrum., Sudarso. 2011. Tingkat Kepuasan Konsumen Apotek Di Kabupaten Banjarnegara. Pharmacy, Vol.08 No. 03.

[34] Yulia., P.R., Baga.M dan Setiadi,D. 2016. Kepuasan Konsumen Terhadap Pelayanan Apotek Dan Tingkat Pengetahuan Konsumen Mengenai Standar Pelayanan Kefarmasian Yang Berlaku (Studi Kasus Di Kota Depok), Jurnal Aplikasi Bisnis dan Manajemen, Vol. 2 No. 3.

[35] Akhmad, A, D., Dirga., Sudewi, M., Nur.,A., Sukrasno. 2019. Tingkat Kepuasan Konsumen Apotek Terhadap Pelayanan Kefarmasian Di Apotek Kecamatan Sukarame. Jurnal Farmasi Malahayati Vol 2 No 1.

[36] Aprilya, V. 2013. Pengaruh Dimensi Kualitas Pelayanan Terhadap Kepuasan Pelanggan J.Co Cabang Padang. Jurnal Manajemen. Vol 2:1. No. 1-9. 